\title{
CULTURE OF RED BEET HAIRY ROOT IN BIOREACTOR AND RECOVERY OF PIGMENT RELEASED FROM THE CELLS BY REPEATED TREATMENT OF OXYGEN STARVATION
}

\author{
Masahiro KinO-OKA, Yasuhiro HONGO, Masahito TAYA, \\ AND SeTsuji TONE \\ Department of Chemical Engineering, Faculty of Engineering Science, \\ Osaka University, Toyonaka 560
}

Key Words: Biochemical Engineering, Plant Cell Culture, Hairy Root, Red Beet, Pigment Production

\begin{abstract}
In the culture of red beet hairy root, the red pigment (mainly betanin) was released from the cells into medium when the cells were subjected to the culture condition under $\mathrm{O}_{2}$ starvation by keeping the concentration of dissolved oxygen in medium at $0 \mathrm{ppm}$. The amount of released pigment increased with increasing time length of $\mathrm{O}_{2}$ starvation during $26 \mathrm{~h}$. However, an $\mathrm{O}_{2}$ starvation time of less than $16 \mathrm{~h}$ was employed to shorten the lag time for cell growth resumption after this starvation treatment. An adsorption column with a hydrophobic resin, Sepabeads SP 207 (styrene-divinylbenzene copolymer), was incorporated in a bioreactor system and the long-term culture of hairy root was carried out with repeated operations of cell growth, pigment release and recovery. In the culture with an $\mathrm{O}_{2}$ starvation time of $16 \mathrm{~h}$, an extracellular production rate of pigment of $11.3 \times 10^{-6} \mathrm{~kg} /\left(\mathrm{m}^{3}\right.$ broth $\cdot h$ ) was obtained on the average.
\end{abstract}

\section{Introduction}

For the last decade, submerged culture of plant cells has been exploited for the production of plantderived products on laboratory and industrial scales. $^{3,4,10)}$ Many plant materials have been employed extensively, ranging in morphology from dedifferentiated cells (callus or suspended cells) to differentiated cells (adventitious shoot and root, hairy root, organ or immature plant). ${ }^{16)}$

In general, however, the growth rates of plant cells are slower than those of microorganisms. In plant cell cultures, therefore, it is of technological importance to sustain high cell mass density in a bioreactor and to utilize the cell mass over a desired period of culture time. For this purpose, it is desirable that the products of interest be released from the plant cells into medium as most products are intracellularly accumulated without secretion.

Several workers ${ }^{1,5,6,13)}$ have proposed methods to leak the intracellular products from the cells, such as the exposure of plant cells to organic or inorganic compounds, electricity, or ultrasound. In these methods, however, it seems likely that the products will be contaminated with the additives and that the heterogeneity of cell suspension prevents effective release of the products.

In our previous paper ${ }^{17)}$ we reported the establishment of a hairy root clone of red beet. The hairy

* Received January 13, 1992. Correspondence concerning this article should be addressed to $\mathrm{S}$. Tone. root possessed the outstanding properties of genetic stability, active propagation and high content of red pigment (mainly betanin). It was found that a singificant amount of the pigment was released into medium by intermitting $\mathrm{O}_{2}$ supply to the hairy root cells in a shake culture. However, it is known that the beetroot pigment is labile in aqueous solution containing metal ions and that degradation of the pigment is promoted by exposure to air. ${ }^{2)}$ So it is desirable that the pigment be removed from medium just after release of the pigment.

The aim of the present study is to perform a submerged culture of the red beet hairy root with repeated operations of cell growth and pigment release. Moreover, a pigment adsorption unit is incorporated into a bioreactor system for the in situ recovery of the pigment without its degradation in medium.

\section{Experimental}

\subsection{Hairy root, medium and culture}

A hairy root clone of red beet (Beta vulgaris $\mathrm{L}$. cv. Detroit dark red), which had been induced by a leaf-disk method with Agrobacterium rhizogenes, ${ }^{17)}$ was used. The hairy root was maintained by subculturing at 2-week intervals.

The hairy root cultures for maintenance and inoculum preparation were carried out in a $0.5-\mathrm{dm}^{3}$ Erlenmeyer flask containing $0.25 \mathrm{dm}^{3}$ of hormonefree Murashige-Skoog (MS) liquid medium ${ }^{11)}$ with $30 \mathrm{~kg} / \mathrm{m}^{3}$ sucrose. The flask was shaken at $100 \mathrm{rpm}$ on a rotary shaker (Model HRS-24, Shibata Hario 
Glass Co.) at $25^{\circ} \mathrm{C}$ in the dark. The medium was autoclaved at $121^{\circ} \mathrm{C}$ for $0.3 \mathrm{~h}$ after $\mathrm{pH}$ was adjusted to 5.7 with $100 \mathrm{~mol} / \mathrm{m}^{3} \mathrm{NaOH}$.

\subsection{Culture operation with bioreactor}

The configuration of the bioreactor systems is depicted in Fig. 1. These systems consisted of one unit each for cell culture and pigment recovery.

As the cell culture unit, a turbine-blade fermentor (working volume: $1.0 \mathrm{dm}^{3}$; Model TBR-2, Sakura Seiki Co.) was used. In this fermentor, a stainless steel mesh separated a culture space $\left(0.6 \mathrm{dm}^{3}\right)$ from an agitation space $\left(0.4 \mathrm{dm}^{3}\right)$ so that the hairy root did not contact an impeller. The culture started with an inoculum of about $1.0 \mathrm{~kg}$-dry cells $/ \mathrm{m}^{3}$ at $25^{\circ} \mathrm{C}$ using MS liquid medium containing $20 \mathrm{~kg} / \mathrm{m}^{3}$ sucrose and $0.05 \mathrm{~kg} / \mathrm{m}^{3}$ antifoam (Silicone KM-72, Shin-etsu Chemical Industries Co.). During cell growth, dissolved oxygen (DO) concentration was measured with a DO meter (Model DO-1, Sakura Seiki Co.), and was controlled at $5 \mathrm{ppm}$ by changing the agitation speed $(150-200 \mathrm{rpm})$ and air flow rate (1.5$\left.9.0 \mathrm{dm}^{3} / \mathrm{h}\right)$. If necessary, sucrose solution $\left(300 \mathrm{~kg} / \mathrm{m}^{3}\right)$ was adequately added to the culture, and the culture broth was exchanged with fresh medium so that electric conductivity of broth did not fall below $0.2 \mathrm{~S} / \mathrm{m}$.

Unless otherwise noted, the operation for pigment release was carried out as follows. The air supply was first stopped and then pure $\mathrm{N}_{2}$ gas was introduced into the fermentor for an hour to drop the DO level substantially to zero. After pigment release for a given time, hairy root growth was resumed by supplying air. To recover the released pigment, the culture broth was circulated through an adsorbent column $(3 \mathrm{~cm} \phi$ by $20 \mathrm{~cm})$ packed with $25 \mathrm{~g}$ resin. Two columns were connected to the fermentor and each was used alternately for the in situ adsorption and desorption of pigment. The columns were washed with sterilized water after pigment desorption.

\subsection{Pigment adsorption with resins}

As adsorbents of red beet pigment, Diaion HP 20, and Sepabeads SP 207 and SP 850 resins (styrenedivinylbenzene copolymers supplied by Mitsubishi Kasei Co.) were examined. These resins have specific surface areas of 605,627 and $995 \times 10^{-3} \mathrm{~m}^{2} / \mathrm{kg}$-resin respectively. Sepabeads SP 207 is a modified type with enhanced hydrophobicity by introduction of a substituent. Prior to use, these resins were soaked in methanol and washed with several volumes of water. A part of the resins was dried at $60^{\circ} \mathrm{C}$ for $48 \mathrm{~h}$ to determine water content and to correct the resin amount on the dry basis.

As an authentic pigment, Sanbeet F (pigment preparation of beetroot procured from San-ei Chemical Industries Co.) in $30 \mathrm{~mol} / \mathrm{m}^{3}$ phosphate buffer $(\mathrm{pH}=6.0)$ was used, unless otherwise noted. A

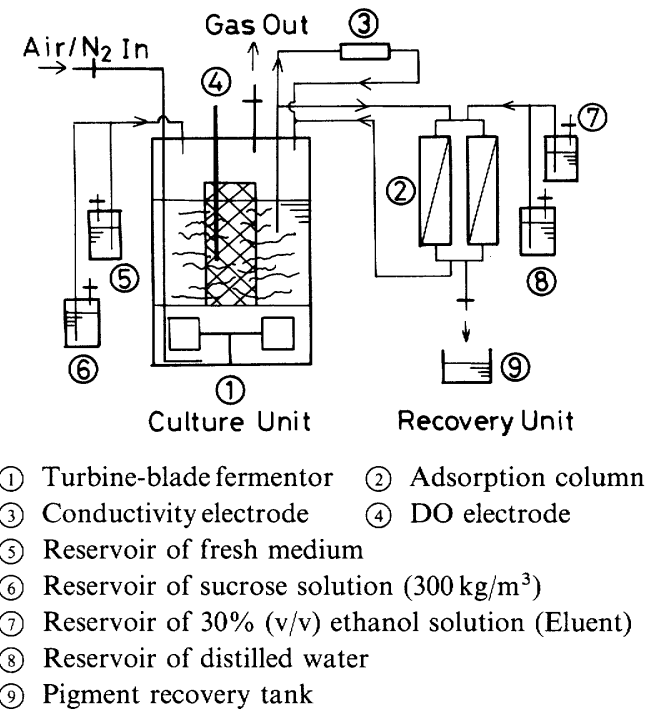

Fig. 1. Schematic diagram of bioreactor systems for red beet hairy root

0.2- $\mathrm{dm}^{3}$ Erlenmeyer flask containing $8 \mathrm{~g}$ resins and $0.1 \mathrm{dm}^{3}$ of the pigment solution was shaken and allowed to equilibrate at $25^{\circ} \mathrm{C}$ for $4 \mathrm{~h}$. After the removal of resins by decantation, absorbance of supernatant was measured to determine pigment concentration (shown hereinafter). The pigment quantity adsorbed on the resins was calculated by Eq. (1).

$$
q=\left\{C_{p, 0} V-C_{p, e q}\left(V_{r}+V\right)\right\} / A
$$

\subsection{Analyses}

For the determination of dry cells, the hairy root was rinsed with water and dried at $60^{\circ} \mathrm{C}$ for $48 \mathrm{~h}$. In the culture with the bioreactor, the dry cells were estimated on the basis of conductometric measurement of medium. ${ }^{18)}$ The empirical equation was $a$ priori determined as follows.

$$
X=-30(\Delta \kappa)+X_{0}
$$

Eq. (2) was valid in the range of $\kappa=0.2-0.6 \mathrm{~S} / \mathrm{m}$.

The oxygen uptake rate and enzymatic reduction of triphenyl tetrazolium chloride (TTC) were used to evaluate the cell viability of hairy root. These measurements were carried out with hairy root cut into $2-3 \mathrm{~cm}$ lengths. The procedure to determine the $\mathrm{O}_{2}$ uptake rate was identical to that of Kim et al. ${ }^{8)}$ The TTC reduction activity was measured according to the method described by Steponkus et al., ${ }^{15)}$ except that a molar extinction coefficient of $88.7 \times$ $10^{-4} \mathrm{~m}^{2} / \mathrm{mol}$ was used for the reaction product (triphenyl formazan).

Sugar concentrations were determined with an LC-6A high-performance liquid chromatograph and an RID-6A refractive index detector (Shimadzu Co.). The analytical condition was the same as that of Kim et al. ${ }^{7)}$ Pigment amounts in cells and in medium (or 
buffer) were spectrophotometrically analyzed as reported earlier ${ }^{17)}$ and expressed as those of betanin (main pigment in red beet). The analyses of ammonium, nitrate and potassium ions were described elsewhere. ${ }^{9)}$

\section{Results and Discussion}

\subsection{Effect of DO concentration on pigment release by hairy root}

In our previous paper ${ }^{17)}$ it was qualitatively demonstrated that the decrease in medium DO level caused pigment leakage from the cells of red beet hairy root in a shake culture. In the present study, the effect of DO concentration on the pigment leakage was first investigated in further detail, using the turbine-blade fermentor. The hairy root was cultivated in advance for $192 \mathrm{~h}$ at $C_{D O}=5 \mathrm{ppm}$ to obtain active growing-cells $\left(X=c a .5 \mathrm{~kg} / \mathrm{m}^{3}\right)$, and then the DO concentration was controlled at $0,1,2$, 4 and $5 \mathrm{ppm}$ by changing the air flow rate and introducing $\mathrm{N}_{2}$ gas into the fermentor, on occasion.

Figure 2 shows the changes of pigment concentration in medium after the onset of DO control at the various levels. When the DO concentration was maintained at $0 \mathrm{ppm}$, the pigment was sufficiently released into medium. At $C_{D O}=1-5 \mathrm{ppm}$, however, the pigment concentration in medium was negligible even after $50 \mathrm{~h}$. The pigment amount in medium increased with the time of DO control at $0 \mathrm{ppm}$ and reached the maximum of $6.68 \times 10^{-3} \mathrm{~kg} / \mathrm{m}^{3}$ at $26 \mathrm{~h}$, which corresponded to $50 \%$ of pigment release ratio from the cells $\left(=100\left(C_{p}\right.\right.$ in medium $) /\left\{\left(C_{p}\right.\right.$ in medium $)+\left(C_{p}\right.$ in cells $\left.\left.)\right\}\right)$. The lowering of pigment release rate at $26 \mathrm{~h}$ may be attributable to the decrease in pigment content in the cells.

Thus, pigment leakage out of the cells was caused only when the hairy root was subjected to the culture condition of $C_{D O}=0 \mathrm{ppm}$ (namely $\mathrm{O}_{2}$ starvation).

\subsection{Growth of hairy root after treatment of pigment release}

For the long-term culture of hairy root and successive pigment production, the cells should be able to propagate without the serious loss of growth ability after pigment release by the $\mathrm{O}_{2}$ starvation treatment.

Therefore, the effect of $\mathrm{O}_{2}$ starvation time on the resumption of hairy root growth was investigated, as shown in Fig. 3. In these experiments, the hairy root was first cultivated for $192 \mathrm{~h}$ at $C_{D O}=5 \mathrm{ppm}$, and then DO concentration was kept at $0 \mathrm{ppm}$ for each period, i.e., $t_{D O=0}=0,12,16,20$ or $26 \mathrm{~h}$. Thereafter, the hairy root cultures started again at $C_{D O}=5 \mathrm{ppm}$ after the culture broth was exchanged for fresh medium. The lag times for growth resumption increased with increasing length of $t_{D O=0}$. The growth ability was hardly suppressed in the culture

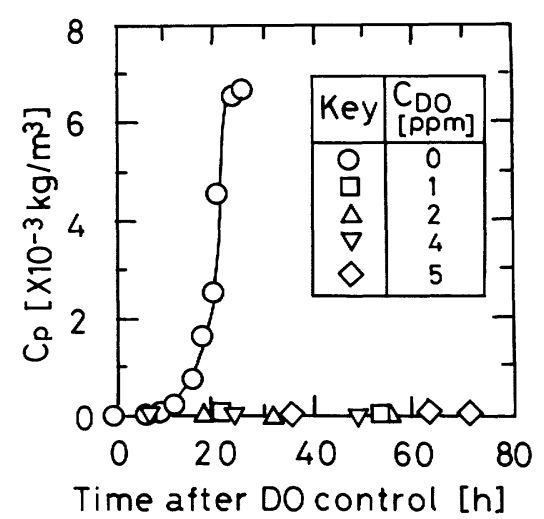

Fig. 2. Change of pigment concentration in medium after DO control at varous levels

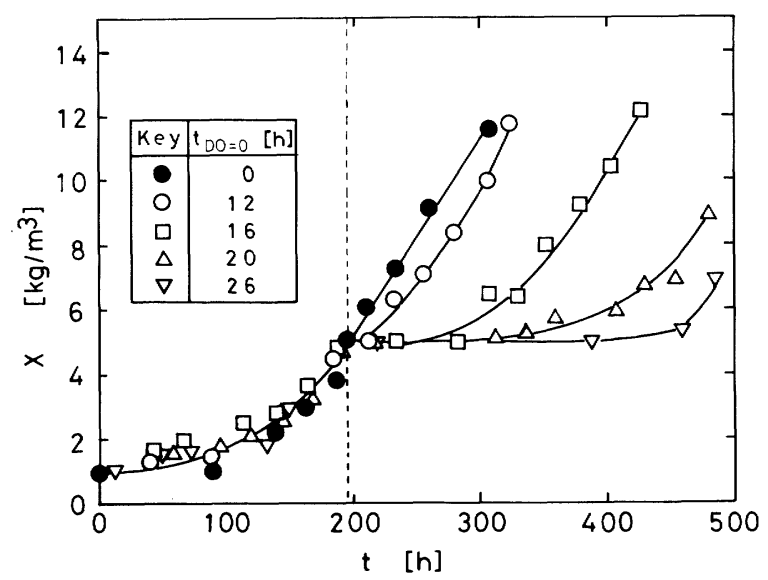

Fig. 3. Effect of $\mathrm{O}_{2}$ starvation time $\left(t_{D O=0}\right)$ on resumption of hairy root growth $\left(C_{D O}\right.$ was maintained at $0 \mathrm{ppm}$ from the time shown by the broken line for the indicated periods.)

with $t_{D O=0}=12 \mathrm{~h}$, compared with the control culture without the $\mathrm{O}_{2}$ starvation. In the culture with $t_{D O=0}=16 \mathrm{~h}$, the lag time was about $70 \mathrm{~h}$. During the $\mathrm{O}_{2}$ starvation times of 12 and $16 \mathrm{~h}$, the pigment release ratios from the cells were 4.2 and $10.1 \%$, respectively (data not shown). A prolonged lag time of about $250 \mathrm{~h}$ was observed in the culture with $t_{D O=0}=26 \mathrm{~h}$. From the viewpoint of utilizing the growing cells over a more extended duration of culture time, an $\mathrm{O}_{2}$ starvation time of less than $16 \mathrm{~h}$ was considered to be valid for pigment release treatment in subsequent experiments.

For the growth of hairy root, it is important to keep the tip growing-points (apical meristems of young cells) alive, because the growth mainly occurs at those points in a one-dimensional direction. To check the cell viability, the hairy root treated by $\mathrm{O}_{2}$ starvation $\left(t_{D O=0}=16 \mathrm{~h}\right)$ was divided into two parts (tip part and origin part other than tips), and the $\mathrm{O}_{2}$ uptake rate and TTC reduction activity of each part were evaluated in comparison with those of active growing-cells without $\mathrm{O}_{2}$ starvation as a control. As shown in Table 1, the values for tip part cells were 
Table 1. Oxygen uptake rate and TTC reduction activity of hairy root as criteria of cell viability

\begin{tabular}{lcc}
\hline & $\begin{array}{c}\mathrm{O}_{2} \text { uptake rate } \\
{\left[\mathrm{mol}-\mathrm{O}_{2} /\right.} \\
(\mathrm{kg} \text {-dry cells } \cdot \mathrm{h})]\end{array}$ & $\begin{array}{c}\text { TTC reduction } \\
\text { activity } \\
{[\mathrm{mol} / \mathrm{kg} \text {-dry cells }]}\end{array}$ \\
\hline $\begin{array}{l}\text { Origin part cells with } \\
\text { 16-h } \mathrm{O}_{2} \text { starvation }\end{array}$ & 0.09 & 0.024 \\
$\begin{array}{l}\text { Tip part cells with } \\
\text { 16-h } \mathrm{O}_{2} \text { starvation }\end{array}$ & 0.20 & 0.095 \\
$\begin{array}{l}\text { Active growing-cells } \\
\text { without } \mathrm{O}_{2} \text { starvation }\end{array}$ & 0.37 & 0.19 \\
\hline
\end{tabular}

at most about $50 \%$ smaller than those of active growing-cells, but the values were much lower for the origin part cells. From visual observation, moreover, the origin part cells were partially lysed and fragile in the state of dark-red pigmentation. These results suggested that the old cells apart from apical meristems were more susceptible to $\mathrm{O}_{2}$ starvation and that the pigment leaked mainly from these cells.

\subsection{Pigment production with bioreactor systems}

1) Selection of pigment adsorbent For the recovery of pigment released into medium, the adsorption approach was examined because it is advantageous for separating and concentrating the product of interest from a dilute aqueous mixture.

Three types of synthetic polymer resins (Diaion HP 20, and Sepabeads SP 207 and SP 850) were tested, using the authentic pigment preparation of beetroot. Figure 4 shows the adsorption isotherms of the resins. Sepabeads SP 207 had the largest capacity to adsorb the pigment. The affinity of this resin to the pigment may result from the enhanced hydrophobicity interacting with the indole and pyridine residues of the pigment. For Sepabeads SP 207 an adsorption experiment was also carried out with medium containing the pigment released from the hairy root. No significant difference was observed between the adsorption data for the authentic and hairy root pigments (symbols $\bigcirc$ and $\bigcirc$ respectively).

In another experiment of pigment desorption with some solvents, $30 \%(\mathrm{v} / \mathrm{v})$ aqueous ethanol solution was found to be valid as an eluent (data not shown). Then a pigment adsorption experiment was done using Sepabeads 207 which had undergone regeneration treatment by eluting adsorbed pigment from the resin with $30 \%(\mathrm{v} / \mathrm{v})$ ethanol. As shown in Fig. 4, the data (symbol ()) closely agree with those using the untreated resin (symbol $\mathbf{O}$ ).

Several workers also applied an adsorption operation with polymeric resins to the production of plant metabolites including anthraquinone, ${ }^{14)}$ indole alkaloids $^{12)}$ and peroxidase. ${ }^{5)}$ However, few data were presented with respect to the interactions between the resins and medium nutrients. As shown

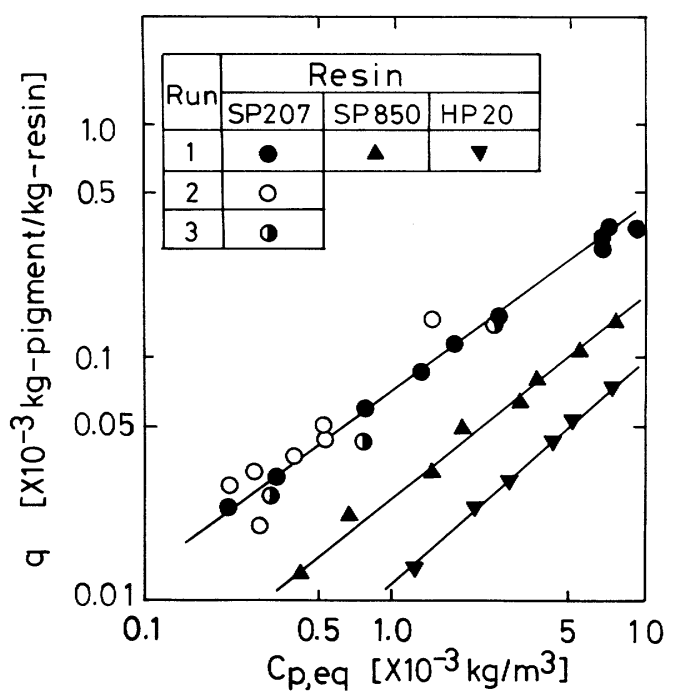

Fig. 4. Isotherms of pigment adsorption with Sepabeads SP 207 and SP 850, and Diaion HP 20 (Run 1: adsorption of authentic pigment; Run 2: adsorption of pigment released by hairy root; Run 3: adsorption of authentic pigment using resin regenerated by eluting adsorbed pigment with $30 \%$ $(\mathrm{v} / \mathrm{v})$ ethanol)

Table 2. Comparison of major nutrient concentrations and cell growth between MS media with and without adsorption treatment with resin (Sepabeads SP 207)

\begin{tabular}{lcc}
\hline & \multicolumn{2}{c}{ Concentration $\left[\mathrm{kg} / \mathrm{m}^{3}\right]$} \\
\cline { 2 - 3 } & without treatment & with treatment \\
\hline Sucrose & 24 & 22 \\
$\mathrm{~K}^{+}$ & 0.77 & 0.74 \\
$\mathrm{NH}_{4}^{+}$ & 0.34 & 0.34 \\
$\mathrm{NO}_{3}^{-}$ & 1.9 & 1.9 \\
$\mathrm{PO}_{4}^{3-}$ & 0.12 & 0.11 \\
Dry cells* & 5.7 & 5.2 \\
\hline
\end{tabular}

* The hairy root was cultivated in each medium for $192 \mathrm{~h}$ in an Erlenmeyer flask.

in Table 2, the concentrations of major nutrients (sucrose, ammonium, potassium, nitrate and phosphate) were compared between MS media treated and untreated with Sepabeads 207. It was recognized that the sugar and ions were hardly lost by adsorption treatment with the resin. Moreover, the hairy root could grow normally in the medium with the resin treatment, indicating that the trace components (vitamins, metals, etc.) remained at sufficient levels to sustain cells growth after the treatment.

2) Culture performance As mentioned above, Sepabeads SP 207 was selected as an adsorbent to be incorporated into the bioreactor system (see Fig. 1). The culture of red beet hairy root was performed with the operations of cell growth, pigment release and adsorption followed by the elution.

Figure 5 shows the time course of hairy root culture. In this culture the hairy root was cultivated 


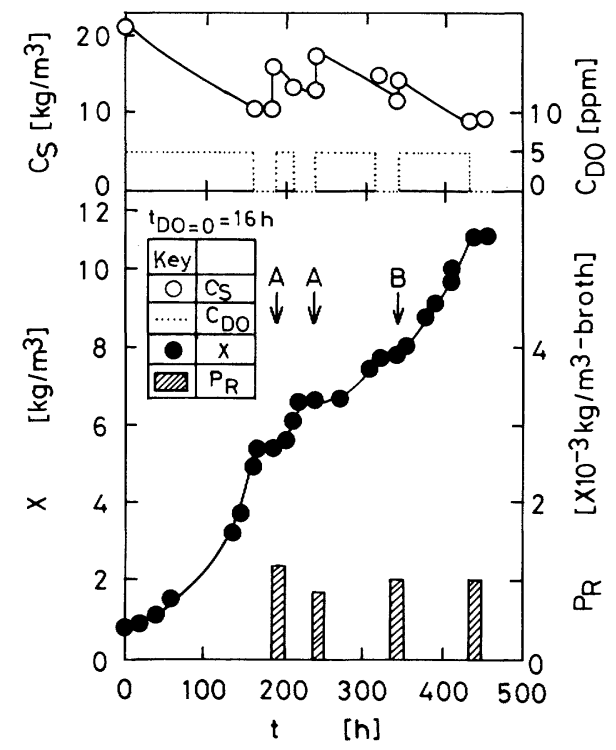

Fig. 5. Culture of hairy root in bioreactor systesms (Arrow A: time of sucrose addition; Arrow B: time of medium exchange)

normally for $172 \mathrm{~h}$, and afterwards the operation of pigment recovery was carried out four times with pigment release by the $\mathrm{O}_{2}$ starvation of $t_{D O=0}=16 \mathrm{~h}$. The amount of pigment produced, $P_{R}$, in each operation was $0.8-1.3 \times 10^{-3} \mathrm{~kg} / \mathrm{m}^{3}$-broth. At the end of culture $(t=450 \mathrm{~h})$, the pigment content of cells was $1.05 \times 10^{-3} \mathrm{~kg} / \mathrm{kg}$-dry cells, suggesting that afterwards the extracellular production of pigment is feasible. Table 3 summarizes the results of hairy root cultures which were performed under almost the same conditions except for the $\mathrm{O}_{2}$ starvation time; $t_{D O=0}=16 \mathrm{~h}$ in Run 1 and $t_{D O=0}=12 \mathrm{~h}$ in Run 2. In both cultures the final concentration of dry cells and the total amount of pigment produced out of bioreactor were $11.1 \mathrm{~kg} / \mathrm{m}^{3}$ and $4.0 \times 10^{-3} \mathrm{~kg} / \mathrm{m}^{3}$-broth (Run 1), and $13.0 \mathrm{~kg} / \mathrm{m}^{3}$ and $1.9 \times 10^{-3} \mathrm{~kg} / \mathrm{m}^{3}$ broth (Run 2), respectively. The extracellular production rate of pigment in the culture of Run 1 was $11.3 \times 10^{-6} \mathrm{~kg} /\left(\mathrm{m}^{3}\right.$-broth $\left.\cdot \mathrm{h}\right)$ on the average-a production rate about 1.7 times as high as that in the culture of Run $2\left(6.7 \times 10^{-6} \mathrm{~kg} /\left(\mathrm{m}^{3}\right.\right.$-broth $\left.\cdot \mathrm{h}\right)$ although the cell growth was somewhat better in the latter culture. The sum of the pigment amounts produced out of bioreactor and retained in cells was almost the same in these cultures, namely $15.7 \times 10^{-3}$ $\mathrm{kg} / \mathrm{m}^{3}$-broth in the culture of Run 1 and $16.6 \times 10^{-3}$ $\mathrm{kg} / \mathrm{m}^{3}$-broth in the culture of Run 2 . Therefore, the increase in the extracellular production rate in the culture of Run 1 was due to the enhancement of pigment amount released from the hairy root cells during the $\mathrm{O}_{2}$ starvation treatment. Thus, the $\mathrm{O}_{2}$ starvation time of $16 \mathrm{~h}$ was preferred for the extracellular pigment production by the hairy root culture.
Table 3. Summary of results obtained from hairy root cultures in bioreactor systems

\begin{tabular}{lcc}
\hline & Run 1 & Run 2 \\
\hline Culture time [h] & 450 & 480 \\
$\mathrm{O}_{2}$ starvation time [h] & 16 & 12 \\
Number of pigment release operations [-] & 4 & 4 \\
$\begin{array}{l}\text { Final concentration of dry cells }\left[\mathrm{kg} / \mathrm{m}^{3}\right] \\
\text { Amount of pigment retained in cells } \\
\quad\left[\times 10^{-3} \mathrm{~kg} / \mathrm{m}^{3} \text {-broth }\right]\end{array}$ & 11.1 & 13.0 \\
$\begin{array}{l}\text { Total amount of pigment produced out of } \\
\text { bioreactor }\left[\times 10^{-3} \mathrm{~kg} / \mathrm{m}^{3} \text {-broth] }\right.\end{array}$ & 41.7 & 14.7 \\
$\begin{array}{l}\text { Average pigment production rate } \\
{\left[\times 10^{-6} \mathrm{~kg} /\left(\mathrm{m}^{3} \text {-broth } \cdot \mathrm{h}\right)\right]}\end{array}$ & 11.3 & 1.9 \\
\hline
\end{tabular}

As mentioned above, it was possible to cultivate the red beet hairy root during the extended period of culture time in the bioreactor system with the operations of pigment release and recovery.

\section{Conclusion}

1) The red beet hairy root released red pigment (mainly betanin) from the cells into medium when the cells received treatment of $\mathrm{O}_{2}$ starvation by maintaining the DO concentration in medium at 0 ppm.

2) A treatment time of $\mathrm{O}_{2}$ starvation less than $16 \mathrm{~h}$ was appropriate, judging from the amount of released pigment and the ability of cells to regrow after the treatment.

3) The hydrophobic resin Sepabeads SP 207 (styrene-divinylbenzene copolymer) was chosen as an adsorbent for the pigment released into medium by the hairy root.

4) The adsorption column with this resin was incorporated in a bioreactor system and the longterm culture of red beet hairy root was performed with repeated operations of cell growth, pigment release and revovery. As the result, the pigment was recovered out of the bioreactor at an average production rate of $11.3 \times 10^{-6} \mathrm{~kg} /\left(\mathrm{m}^{3}\right.$-broth $\left.\cdot h\right)$.

\section{Acknowledgement}

The authors are grateful to Dr. M. Kawase (NGK Insulators Ltd.), and to Messrs. K. Odake and T. Ichi (San-ei Chemical Industries Ltd.) for their invaluable discussions. The authors also wish to thank Mr. R. Sugimoto (Mitsubishi Kasei Co.) for generously supplying the polymer resins. This work was supported in part by a Grant-in-Aid for Co-operative Research (No. 02303014) from the Ministry of Education, Science and Culture of Japan.

\footnotetext{
Nomenclature

$A \quad=$ weight of adsorbent $\quad[\mathrm{kg}]$

$C_{D O} \quad=$ DO concentration $\quad[\mathrm{ppm}]$

$C_{S} \quad=$ sugar concentration as glucose equivalent $\left[\mathrm{kg} / \mathrm{m}^{3}\right]$

$C_{p} \quad=$ pigment concentration $\quad\left[\mathrm{kg} / \mathrm{m}^{3}\right]$

$C_{p, 0}=$ initial concentration of pigment in aqueous phase $\quad\left[\mathrm{kg} / \mathrm{m}^{3}\right]$
} 


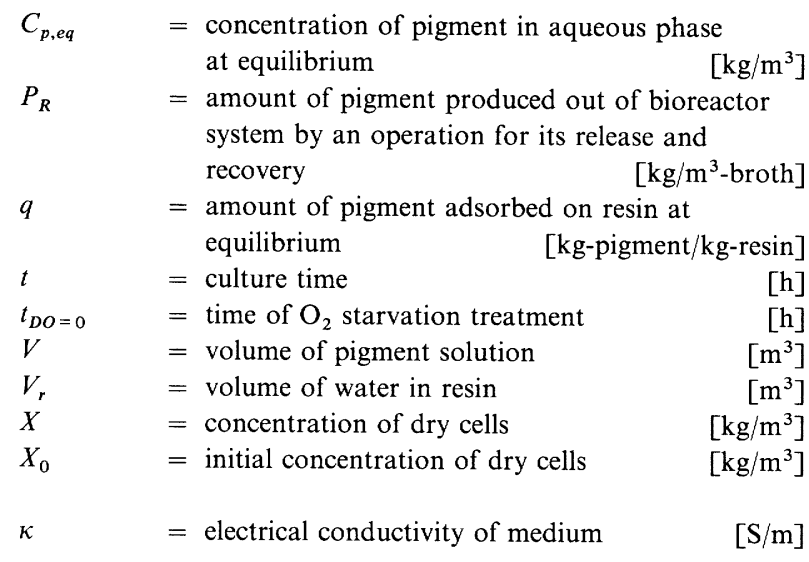

\section{Literature Cited}

1) Brodelius, P. E.: Appl. Microbiol. Biotechnol. 27, 561 (1988).

2) von Elbe, J. H., I.-Y. Maing and C. H. Amundson: J. Food Sci., 39, 334 (1974).

3) Fujita, Y., C. Suga, K. Matsubara and Y. Hara: Nippon Nogeikagaku Kaishi, 60, 849 (1986).

4) Furusaki, S., T. Nozawa, T. Isohara and T. Furuya: Appl. Microbiol. Biotechnol., 29, 437 (1988).

5) Kato, Y., N. Uozumi, T. Kimura, H. Honda and T. Kobayashi: Plant Tissue Culture Lett., 8, 158 (1991).

6) Kilby, N. J. and C. S. Hunter: Appl. Microbiol. Biotechnol.,
34, 478 (1991).

7) Kim, D., H. Pederson and C. K. Chin: Biotechnol. Bioeng., 38, 331 (1991).

8) Kim. D. J. and H. N. Chang: Biotechnol. Bioeng., 36, 460 (1990).

9) Kino-oka, M., M. Taya and S. Tone: J. Chem. Eng. Japan, 24, 381 (1991).

10) Matsusita, T., K. Ishibashi, M. Kizu and K. Funatsu: Kagaku Kogaku Ronbunshu, 17, 649 (1991).

11) Murashige, T. and F. Skoog: Physiol. Plant., 15, 473 (1962).

12) Payne, G. F. and M. L. Shuler: Biotechnol. Bioeng., 31, 922 (1988).

13) $\mathrm{Pu}, \mathrm{H}$. T., R. Y. K. Yang and F. L. Saus: Biotechnol. Lett., 11, 83 (1989).

14) Robins, R. J. and M. J. C. Rhodes: Appl. Microbiol. Biotechnol., 24, 35 (1986).

15) Steponkus, P. L. and F. O. Lanphear: Plant Physiol., 42, 1423 (1967).

16) Takayama, S. "Bioprocess Engineering", pp. 64-75, CMC Press Co., Tokyo (1985).

17) Taya, M., K. Mine, M. Kino-oka, and S. Tone: J. Ferment. Bioeng., 73, 31 (1992).

18) Taya, M., M. Hegglin, J. E. Prenosil, and J. R. Bourne: Enzyme Microb. Technol., 11, 170 (1989).

(Presented at the 24th Autumn Meeting of the Society of Chemical Engineers, Japan, at Nagoya, October 16, 1991) 